\title{
Professional characteristics and level of competence of receiving teachers on mainstreaming
}

Guzman, Sammy Boy $\bowtie$

Far Eastern University - Roosevelt College, Philippines (sammyboy.guzman@deped.gov.ph)

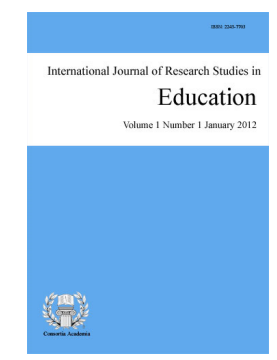

ISSN: $2243-7703$ Online ISSN: 2243-7711

OPEN ACCESS

\section{Abstract}

This descriptive method of study aimed to determine the Professional Characteristics and Level of Competence of Receiving Teachers on Mainstreaming. Results indicated that: (1) Receiving teachers were composed of baccalaureate and master's degree holders. Receiving teachers do not have a long-time experience in teaching children with special needs. Majority of the receiving teachers have no trainings/ workshops related to special education. They are also lacking of course in college related to educating children with special needs; (2) Receiving teachers perceived themselves proficient in the three areas including development and characteristics of learners, assessment and curriculum, and collaboration with parents and other professionals. Experts perceived that receiving teachers are competent in the areas of development and characteristics of learners, and assessment and curriculum. However, receiving teachers were proficient with the area of collaboration with parents and other professionals; (3) Significant relationships were identified between the educational attainment, number of years in teaching children with special needs, and number of special education trainings and workshops attended, to the receiving teachers' level of competence. Meanwhile, there is no significant relationship that existed between the number of courses taken in college related to educating children with special needs and receiving teachers' level of competence; (4) Significant differences exist between the receiving teachers' self-assessment and experts' assessment in all areas of receiving teachers' competence on mainstreaming. Receiving teachers overestimated their performance and they perceived it higher than the experts.

Keywords: receiving teachers; teachers' competence; professional characteristics; mainstreaming; special education; inclusive education 


\section{Professional characteristics and level of competence of receiving teachers on mainstreaming}

\section{Introduction}

Special Education provides a wide range of supports, programs, and services. It continues developing its features in order to cater the needs of people with exceptionalities/ disabilities. Research has shown that the most effective means of educating students with disabilities is in the general education classroom with their normally developing peers (Boyle \& Topping, 2012). Special education in the Philippines is on the right path, because it is now in the phase of strengthening the meaningful linkages between special and general education classrooms. Special education teachers are required to take courses during their teacher education programs in the classroom management and behavior management of students with disabilities, including students with emotional and behavioral disabilities, general education teachers generally do not receive the same training (McCray \& McHatton, 2007). General Education teachers should be aware that they are essential to the success of all students, not just for general education students. This could be accomplished through targeted professional development and professional learning communities designed to help general educators recognize their importance to the education of all students (Vescio, Ross, \& Adams, 2008).

The rationale for this research is underpinned by several factors: mainstreaming program can cater different categories of disability and receiving teachers are obliged to ensure that these students must receive quality education that is appropriate to their needs; the receiving teachers of locale of the study have been engaged in teaching children with special needs in the past five years and the responsibility of the school and government of ensuring that these receiving teachers have the essential relevant trainings in special education; Philippine education setting is on its way to make every school as a mainstreaming school, so there should be a progress research in the areas of special education, and receiving teachers' professional characteristics and level of competence on mainstreaming. The roles of receiving teachers are changing; equally important is to ensure that intervention programs currently available reflect these changes.

\subsection{Mainstreaming of children with special needs}

Placement program is one of the most improved and dynamic parts of special education. Placement refers to the amount of time in each school day that a student spends in the special or in a general education classroom. Mainstreaming is one of the many educational placements. Mainstreaming is a selective placement of special education students in one or more regular education classes where assumptions are made regarding a student earning the opportunity to be mainstreamed and his or her ability to keep up with coursework (Vazquez, 2010). Some subjects of children with special needs are taught in the special class and some are in the general education classroom.

During the past decade, a considerable body of research has emerged in the field of special education focusing on mainstreaming programs. However, despite this high research interest, several issues remain underexplored when it comes to strengthening the professional characteristics and level of competence of Receiving Teachers on mainstreaming. Schools need to focus first on the best tool that they can have in order to make mainstreaming successful, that are the teachers. Mainstreaming sounds pleasing to the ears, but the beauty of its facets would not be profitable to the children with special needs if it is not implemented by the qualified and competent special education teachers and receiving teachers.

\subsection{Professional characteristics and level of competence of receiving teachers}

Blanton, Pugach, and Florian (2011), on behalf of the American Association of Colleges for Teacher 
Education (AACTE) and the National Center for Learning Disabilities (NCLD) discussed the policy that lays out five components of a vision for the future and identifies opportunities to support teacher education reform: 1.) All teachers are prepared to act on the belief that all students, including students with disabilities, belong in general education classrooms. 2.) All teachers are prepared to treat all students, including students with disabilities, as capable learners who are entitled to high-quality instruction and access to challenging content that fully prepares them for careers and postsecondary education. 3.) All teacher candidates complete their initial preparation with the knowledge and skills necessary to successfully enter the profession and meet the instructional needs of students with disabilities. 4.) State and federal policy invest in high-quality teacher preparation for all candidates, while assuring that every new teacher is qualified with demonstrated skill to educate students with disabilities. 5.) All providers of teacher education embrace preparation for diverse learners as a core component of their mission, prioritizing it, strengthening it, and funding it accordingly.

The Panama-Buena Vista Union School district teachers are crying out in frustration over a lack of preparation, training and breakdowns in communication. Teachers say the plan has been rolled out with little training and it's hindering the quality of instruction for special-needs and general education students. Administrators held no special training for general education teachers on how to instruct students with mild and moderate learning disabilities. The people who can help the general education teachers with respect to those individual students are those special education specialists. There are kids with individualized educational plans in regular education classrooms functioning very well. Those kids deserve regular education in a general education classroom with support. If they can succeed in a class, teachers have to do everything they can to make that happen and give teachers the tools to succeed (Pierce, 2016).

Under federal pressure to increase the amount of time special education students spend in general education classrooms, the California Commission on Teacher Credentialing announced it will require all future teachers to learn techniques proven to foster the success of students with disabilities, including small group instruction, behavior management and using frequent informal assessments to identify and address learning gaps. Among the new requirements for teacher preparation, which go into effect in the 2017-2018 academic year, are instructions in what's known as multi-tiered systems of supports, in which academic and behavioral instruction are given with various levels of specificity, as well as training in how to co-teach a class with a special education teacher. Some programs provide training in how to manage student behavior and how to use data from assessments to provide targeted support. They include using strategies that have been shown to improve engagement and comprehension, such as presenting "digestible" amounts of text, engaging in a brief discussion with the class, and then presenting another chunk of material (Adams, 2015).

The study of Oluremi (2015) found out that the two most commonly held qualifications of teachers who worked with students with special educational needs in the schools of each state were National Certificate of Education (N.C.E.) Certificate and Bachelor of Education (B. Ed.) Certificate. The teachers with certificates in special education were fewer in numbers in all states. The analysis indicated that special education teachers who had undergone training on teaching students with special needs were inadequate in number. Furthermore, the workshops, seminars, and conferences attended by teachers had developed the teachers' attitude to students with special needs. The present study also found out that teachers' exposure to special education courses enabled them in identification and management of special needs children. The researcher suggested that for effective administration of special education, both regular teachers and special educators require regular orientation on how to manage special needs children. The study as well showed that specialist teachers were inadequate in mainstream public secondary schools in Southwestern Nigerian. The problem of inadequate special personnel might contribute to poor academic performance of students with special educational needs. The study of Oluremi (2015) is related to the present study because it investigated the professional characteristics of the teachers who are teaching students with special educational needs. The respondents of previous and present study are both special and general education teachers.

Gorman and Drudy (2011) investigated the professional development for teachers working in special 
education/ inclusion in mainstream schools in Dublin. Researchers found out that most teachers had undertaken some type of in-service in special education. One-eight did not have any professional development or in-service of any type in special education. Overall, 37 percent of teachers did not have any qualification in special educational needs and this was statistically significantly greater at primary level. In general, previous research on the professional needs, roles and responsibilities of teachers with responsibility for special educational needs showed that professional development which was longer in duration, regular, structured, collaborative and embedded in practice was more effective. The evidence shows that the education and support of children with special needs demands highly educated, skilled, and professionally autonomous and committed teachers who can adapt teaching and curricula to the needs and resources of pupils with learning and other difficulties, and for school leaders who are change agents in the development of their schools. Thus, previous research illustrated that teacher education and continuing professional development are at the core of the development of more educational systems. This study of Gorman and Drudy (2011) is related to this study for it deals with the importance of professional characteristics and continuing professional development of teachers working in special education. The previous study differs from this study in the sense that the cited research received responses from primary school principals and teachers, whereas; the present study involves teachers of special and general education under the mainstreaming program.

The study done by Bruster (2014) found out that general education teachers need targeted professional development to teach them how to manage classrooms, structure lessons for student engagement, as well as behavior intervention techniques for students with disabilities. The special education teacher should have the opportunity to model special education pedagogical strategies in the general education classrooms, such as providing multiple means of presenting information and knowledge, accepting multiple means of expressing that knowledge, and utilizing multiple means of engaging all students. This is accomplished with strategies, such as differentiated instruction, which help all students achieve curriculum goals. Bruster (2014) recommended that there should be more special education training at college level for preservice general education teacher preparation, as well as those in educational leadership and administration. Every pre-service educator and school administrator should be required to take classes in the following two areas: classroom management for classes combined by general and special education students and benefits of special education students in general education class. The study of Bruster (2014) is related to the present study for it also emphasized the importance of meaningful collaboration between special and general education teachers. The respondents of the previous and present studies were both special and general education teachers. The previous study differs from this study for the reason that the previous study was for high school level while the present study is for elementary level.

Power (2010) highlighted the area of teacher training and qualifications, physical education teachers' attitudes and experiences of teaching students with disabilities, and barriers to physical education and time allocation for physical education. The researcher's assessment of initial teacher training and academic preparation of physical education teachers indicated that six participants $(50 \%)$ had not received any training or qualifications in the area of adapted physical activity or adapted physical education during their primary physical education degree. It would be possible to surmise that physical education teachers do not have the skills necessary to adapt their physical education classes for students with disabilities, as a result of poor or inadequate initial teacher training. If the study revealed a lack of initial teacher training in the area of special education needs in physical education, then it is reasonable to infer that similar deficiencies occur in other schools throughout Ireland. The lack of initial teacher training has many implications. The first port of call must be in the colleges/ universities. Improvements have been made to the development of modules at undergraduate level to address the issue of special educational needs in physical education. Due to the lack of initial teacher training and the length of time teachers have been teaching physical education, it could be fair to say that at present students with disabilities are not receiving adequate physical education or getting equal opportunities to participate in physical education as physical education teachers simply do not have the training, skills, knowledge or know how to adapt physical education classes to meet their needs. The researcher stated that a physical educator's attitude towards including students with disabilities in their class was related to the levels of 
special education training received and experience in working with students with special educational needs. The study of Power (2010) is related to the present study because it scrutinized the teacher training and professional characteristics in teaching mainstreamed class. The previous study also provided implications from the results.

The study of Olinger (2013) focused on the factors that enable them to successfully incorporate students with special needs into the general education class in an elementary school setting. The study revealed that teamwork and resources were the strongly needed supports. Special and general education teachers need some type of negotiation that must occur in the classroom in terms of expectations. The respondents also agreed upon the importance of establishing rapport with one another in order to create a positive environment for facilitating communication and collaboration. The interview revealed that resources were also needed. The respondents stated more instructional time is needed to accommodate the students' needs and plan for their learning. Because there can be such a variety of skill levels in a classroom, the teacher tries to work with each child to meet his or her individual needs. The study conducted by Olinger (2013) is similar to the present study because the researcher focused on the collaboration between special and general education teachers. Specifically, the researcher mentioned that teamwork and resources are important factors to successfully incorporate a student with disability in a general education class.

The study of Buenaventura (2009) discovered the challenges experienced by the special and general education teachers. The challenges are divided in three domains: teaching and instruction, assessment, and parents' involvement. In the area of teaching, three themes were highlighted. One of these is physical condition with identified challenges such as small classroom size and far distance of school to the child's home. Another one is the social and economic condition wherein challenges are in the attitude of other students to children with special needs and the lack of financial resources of some parents to support their children. Last on the teaching domain is instruction, wherein lack of equipment/material and training are identified. Teachers identified that they need further training for special education and acquisition of tools for teaching. In the area of assessment, challenges were school facilities for assessment, lack of teachers in screening children, lack of screening materials and limited training in identifying children with special needs were identified. On the other hand, family related challenges were the financial ability of the family to afford assessment. In the parents' involvement, the problem is the acceptance of the parents that their child has developmental conditions. Once identified, another challenge is in initiating the intervention and continuous coordination with the parents. Since special education requires more resources and time, parents without enough resources usually discontinue or reduce support for their child's intervention program. The study of Buenaventura (2009) is related to the present study in terms of its respondents. The previous study utilized a face-to-face in-depth interview. However, the present study used a self-made questionnaire.

The study of Yao (2015) found out some of the basic instructional strategies exhibited in the classroom by general education teachers: a.) offers a range of appropriate materials for age group and learning tasks, b.) offers appropriate activities for child' s Individualized Educational Plan objectives, c.) positions, handles, and moves child in a functional and age appropriate manner, d.) routine physical care is done in functional and age appropriate manner, e.) uses appropriate teaching strategies for child, f.) uses effective prompts for age group and learning tasks, g.) child's attention span is accommodated, h.) allows child sufficient practice, i.) transitions flow smoothly without disruption, j.) uses positive methods to deal with problem behavior, k.) allows time for child to respond, 1.) separate emotions from behavior management, and m.) feedback is enthusiastic, sincere, specific, and positive. The study of Yao (2015) is related to the present study because it tackled the expected instructional strategies that a general education teacher must exhibit in the classroom. The previous and present study shared a common goal, and that is to gauge the awareness of general education teachers regarding their role as part of the mainstreaming program.

The study of Manansala (2008) evaluated the shadow teaching scheme of schools in San Juan and Quezon City. The study identified problems of teachers regarding their communication in terms of the lessons to be taught inside the regular classroom. The problems and concerns were divided into four such as curriculum 
planning, instruction, behavior management, and team working. In terms of curriculum planning, their problems are: lessons are not part of the child's individualized educational plans and inappropriateness of the lessons in the class in relation to the needs and abilities of the child. In terms of instruction, they found that it is difficult to break down the lesson into simpler tasks. In terms of behavior management, their concern is the well-versed applications of the different methods of behavior modification. In terms of team working, their problem is the unrealistic goals set by the other professionals. The study of Manansala (2008) is related to the present study because it discussed the problems and concerns of general education and shadow teachers in terms of collaboration with other professionals.

Ways to Improve Mainstreaming Program

The ultimate goal of special education shall be the integration or mainstreaming of learners with special needs into the regular school system and eventually in the community. One of the strategies for expanding access for people with disabilities mentioned by Inciong (2007) is enhancing special education centers. The centers are tasked with the following: 1.) conduct continuous assessment of children with special needs; 2.) provide in-service training to school personnel, parents and others involved in the child's life on "why" and "how" of creating inclusive schools as well as other relevant educational trends and practices; 3.) produce and provide appropriate teaching and student materials; and 4.) provide support to children with special needs included in the regular classroom in terms of planning instruction and providing a range of educational services in collaboration with the regular teachers. The center does not only focus on enrolling the child with disabilities in the regular classroom but also attempts to assist the regular education teacher and other personnel to respond to the diverse needs and abilities of these children through the provision of appropriate educational programs along with curricular modification and individualized support services (Inciong, 2007).

Special Education Act (2007), Senate Bill No. 517, introduced by Senator Jinggoy Ejercito Estrada, proposed the establishment of special education centers in strategic places to be able to provide accessible services for children with special needs. The Special Education Center shall function as the Resource Center for the implementation of inclusive education that will accept all kinds of children in regular school. It shall a) support children with special needs integrated/included in regular school; b) assist in the conduct of school-based training; c) produce appropriate teaching materials; and d) conduct assessment of children with special needs.

Acero (2008) cited one of the Philippine legislations that contributed to the development of the Special Education sector. The Presidential Decree No. 603: The Child and Youth Welfare Code of the Philippines included the Children with Special Needs. This decree stipulates the following: 1.) The physically or mentally handicapped child shall be given the treatment, education and care required by his particular condition; 2.) The emotionally disturbed or socially maladjusted child shall be treated with sympathy and understanding, and shall be entitled to treatment and competent care; 3 .) The gifted child shall be given opportunity and encouragement to develop his special talents; 4.) Every child has the right to a well-rounded development of his personality to the end that he may become a happy, useful and active member of society.

The theory that supports this research is the foundational work of Bandura (1977). Bandura developed the Social Cognitive Theory (SCT) which describes the interrelationship among behavior, environmental factors, and personal factors and their influence on actions.

According to Social Cognitive Theory, a person acquires knowledge as his or her environment converges with personal characteristics and personal experience. New experiences are evaluated in comparison with the past; prior experiences help to subsequently guide and inform the person as to how the present should be investigated. This study investigated whether there is a relationship between teachers' professional characteristics and level of competence on mainstreaming. Social cognitive theory provides a framework for understanding, predicting, and changing human behavior (Bandura 1986). This study seeks information pertaining to educational attainment, experience, and training/ workshops attended about special education, and compares these to the actions applied at schools with regards to mainstreaming of students with disabilities in the

48 Consortia Academia Publishing (A partner of Network of Professional Researchers and Educators) 
general classroom.

In the Social Cognitive Theory model, the interaction between the person and behavior involves the influences of a person's thoughts and actions. The interaction between the person and the environment involves human beliefs and cognitive competencies that are developed and modified by social influences and structures within the environment (Bandura 1986). This study inquired the teachers' beliefs on educating children with disabilities. Some teachers believe that students with disabilities should be taught full-time in special classrooms or taught in special classrooms but should have some time each day to go to regular classrooms. The belief of teachers would precisely affect their actions and/or performance in teaching children with special needs under the mainstreaming program.

The third interaction, between the environment and behavior, involves a person's behavior determining the aspects of their environment and in turn their behavior is modified by that environment. "Most human behavior is learned observationally through modeling: from observing others, one forms an idea of how new behaviors are performed, and on later occasions this coded information serves as a guide for action" (Bandura, 1986). Social Cognitive Theory is helpful for understanding and predicting both individual and group behavior and identifying methods in which behavior can be modified or changed (Vazquez, 2010). According to Bandura, expectations such as motivation, performance, and feelings of frustration affect behavioral reactions. "What people think, believe, and feel affect how they behave" (Bandura, 1986). For this reason, how people behave can often be better predicted by the way they think. This study will seek to understand the relationship between teachers' competence as perceived by them and competence as perceived by experts.

The study of Marquardt (2009) gave the researcher the insights on his study. Marquardt found that the general education and special educators both have important roles to play in order for the education of all children to be beneficial. It is essential that they work collaboratively as a team. Both principals and teachers need the proper training and education in the area of special education to fully engage in a prosperous special education program.

The medical model of disability sees the person with the disability as the problem. The onus is on them to fit in and adapt to society as it is. If the person with the disability cannot function in society, then he or she should be removed and placed in an institution or isolated at home (Barnes, Mercer \& Shakespeare, 1999). Classrooms are a miniature of society. In this model, the person with disability who cannot function in society should be removed or isolated, then placed in an institution. In the mainstreaming, students with disabilities who cannot perform well in a certain subject will be removed and put in special classes, then will be back if the subject is appropriate in child's ability.

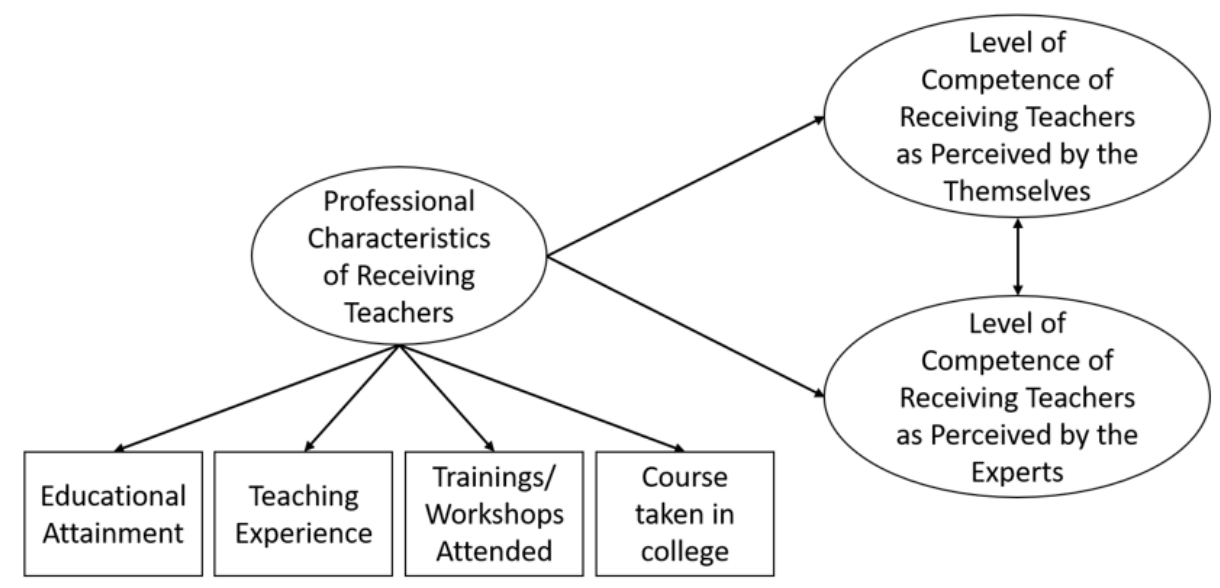

Figure 1. Conceptual model showing the relationships of the variables 
This study took the professional characteristics of teachers such as educational attainment, teaching experience, training/ workshops attended and courses taken in college related to educating children with special needs are the independent variables that may affect the teachers' competence on mainstreaming. The level of competence of receiving teachers as perceived by them and by the experts includes development and characteristics of learners, assessment and curriculum, and collaboration with parents and other professionals are the dependent variables that helped the researcher to fully understand the factors or variables that may affect the process of mainstreaming. The result of the study may serve as a basis in preparing an intervention program for receiving teachers.

\section{Methodology}

The descriptive method of research was used to gather data from the respondents. A descriptive research attempts to describe, explain and interpret conditions of the present i.e. "what is". The purpose of a descriptive research is to examine a phenomenon that is occurring at a specific place and time. A descriptive research is concerned with conditions, practices, structures, differences or relationships that exist, opinions held processes that are going on or trends that are evident (Picciano, 2004). The researcher deemed the descriptive method appropriate for the study.

\subsection{Locale of the study}

This study was conducted at Kasiglahan Village Elementary School, which is a public, non-sectarian school that operates elementary education for both regular and special education and is located in Kasiglahan Village, San Jose, Rodriguez, Rizal. As of school year 2016-2017 it has two hundred two (202) teachers.

\subsection{Respondents of the study}

There are two hundred two (202) teachers in Kasiglahan Village Elementary School, and thirty-nine (39) of them served as the respondents of this study. Out of thirty-nine (39) teachers, thirty-seven (37) of them are Receiving Teachers and two (2) of them are Special Education Teachers which also served as expert evaluators in this study. The respondents covered all the receiving teachers of school year 2016-2017, all of them are working with children with special needs under mainstreaming programs, and gave their consent to participate in the study. The respondents are divided into two (2). The first group consisted of thirty-seven (37) receiving teachers. The second group of respondents consisted of the two (2) Special Education Teachers which served as expert evaluators who have direct observational knowledge of the receiving teachers' competencies in the school environment. They are also the current coordinators in school and district for special education.

\subsection{Research instrument}

The research instrument used in this study is a two-part questionnaire which the researcher constructed and administered to the respondents. The questionnaire is for the teachers and experts.

The first part of the questionnaire is for the teachers' professional characteristics regarding their educational attainment, number of years in teaching children with special needs, number of special education training/ workshops attended and courses taken in college related to educating children with special needs. The second part contained the teachers' level of competence that gauged how competent they are regarding development and characteristics of learners, assessment and curriculum, and collaboration with parents and other professionals. In the second part the teachers and experts checked the 5 (Expert), 4 (Proficient), 3 (Competent), 2 (Advanced Beginner), and 1 (Novice). The questionnaire on level of competence was adapted from books and other internet sites included in the references. It was also elaborated following a thorough review of relevant literature.

For the purpose of content, cultural appropriateness, and fairness validation, the questionnaire was examined by asking experts to judge whether the items cover all aspects of the domain intended to be measured. The

50 Consortia Academia Publishing (A partner of Network of Professional Researchers and Educators) 
questionnaire was subjected to a dry-run among the teachers in Maria Domenica Development Center, Kingsville Subdivision. The revisions made were based on the suggestions. After corrections, the survey questionnaires were distributed to the respondents from Kasiglahan Village Elementary School.

\subsection{Data-gathering procedure}

This research relied mostly on the questionnaire that was answered by the teachers and experts. The researcher sought permission from the Schools Division Superintendent of Rizal. A letter of request duly signed and approved by the Dean of the Roosevelt College Graduate School of Education was given to the Schools Division Superintendent of Rizal. After the approval of the superintendent, the researcher discussed personally with the principal the dynamics of conducting the study, with clarification that the activity would not disrupt nor interfere with the teachers' schedule of classes. The researcher then distributed the questionnaire to the teacher-respondents and experts which they retrieved after a week. After gathering all the data needed in the study, the responses were subjected to appropriate statistical treatment and analysis was employed for the correct interpretation of data.

\subsection{Data analysis and statistical treatment}

Several statistical formulae were used to answer the statement of the problem of this study. Statement of the problem for professional characteristics of receiving teachers was analyzed using frequency and percent. The level of competence of receiving teachers was analyzed using weighted means. Interpretation of the weighted mean is as follows: 1.00-1.49 = Novice, 1.50-2.49 = Advanced Beginner, 2.50-3.49 = Competent, 3.50- 4.49= Proficient and 4.50-5.00 = Expert. Relationship between professional characteristics and teachers' level of competence as perceived by the experts was analyzed using chi-square. Moreover, the significant difference in the teachers' level of competence as perceived by the teachers and experts was analyzed using t-test.

\section{Results and discussions}

Table 1.1

Educational attainment of receiving teachers

\begin{tabular}{ccc}
\hline Educational Attainment & Frequency & Percent $(\%)$ \\
\hline Baccalaureate & 30 & 81.1 \\
Master's Degree & 7 & 18.9 \\
Doctoral & 0 & 0 \\
\hline
\end{tabular}

Table 1.1 shows that out of thirty-seven (37) receiving teachers, 30 or $81.1 \%$ are baccalaureate degree holder and 7 or $18.9 \%$ are with master's degree. The table reveals that the respondents were composed of receiving teachers with baccalaureate and master's degree however, none of them holds a doctoral degree. Through a detailed investigation in the questionnaire, the researcher also discovered that the specializations of the receiving teachers whether baccalaureate or master's degree are not aligned with special education. The receiving teachers' specializations are focused on content and subject courses which allows them for a greater depth and breadth of content specific knowledge in the general education classroom. Some of the receiving teachers are not education major, they just earned education units. However, they all passed the Licensure Examination for Teachers.

As explained by Blanton, Pugach, and Florian (2011), the support that the teachers needed were in terms of proper preparation before entering the profession. Receiving teachers must be prepared with knowledge and skills to meet the instructional needs of students with disabilities. Receiving teachers can cater the needs of students with disabilities through improving their educational attainment.

Table 1.2 shows that 11 or $29.7 \%$ of 37 receiving teachers have less than 1 year experience in teaching children with special needs, 13 or $35.2 \%$ receiving teachers have 1 year teaching experience, 7 or $18.9 \%$ 
receiving teachers have 2 years teaching experience, 4 or $10.8 \%$ receiving teachers have 3 years teaching experience, 2 or $5.4 \%$ receiving teachers have 4 years teaching experience and none of the receiving teachers possesses teaching experience higher than 4 years. An obtained mean of 1.3 or 1 year and 3 months, suggest that, generally, the receiving teachers do not have a long-time experience in teaching children with special needs. Given that the mainstreaming program in the school is on its establishing stage, they have been catering children with special needs in the regular classroom for about five (5) years. Similar to the study of Buell, Hallam, Gamel-McCormick, and Scheer (1999) found that the majority of receiving teachers reported needing more in-service trainings and experience regarding teaching children with special needs.

\section{Table 1.2}

Number of years in teaching children with special needs

\begin{tabular}{ccc}
\hline Number of Years in Teaching & Frequency & Percent $(\%)$ \\
\hline$<1$ & 11 & 29.7 \\
1 & 13 & 35.2 \\
2 & 7 & 18.9 \\
3 & 4 & 10.8 \\
4 & 2 & 5.4 \\
\hline Mean & \multicolumn{3}{c}{1.3 years } \\
\hline
\end{tabular}

Table 1.3

Number of special education trainings/ workshops attended

\begin{tabular}{ccc}
\hline Number of Trainings/ Workshops & Frequency & Percent (\%) \\
\hline 0 & 18 & 48.7 \\
1 & 11 & 29.7 \\
2 & 3 & 8.1 \\
3 & 3 & 8.1 \\
4 & 2 & 5.4 \\
\hline
\end{tabular}

Table 1.3 shows that 18 or $48.7 \%$ of the receiving teachers have zero (0) training/ workshop attended, 11 or $29.7 \%$ of the receiving teachers have one (1) training/ workshop attended, 3 or $8.1 \%$ of the receiving teachers have two (2) trainings/ workshops attended, 3 or $8.1 \%$ of the receiving teachers have three (3) trainings/ workshops attended and 2 or $5.4 \%$ of the receiving teachers have four (4) trainings/ workshops attended. It also shows that the majority of the receiving teachers do not have training and workshops. Obviously, the training and workshops for receiving teachers are badly needed. Special Education is considered a minority in the public school system; it is one of the least priorities. The budget is allotted for additional facilities and amenities of school. Receiving teachers can acquire training and workshops through the volunteer organizations which grant it for free.

Similarly, the analysis of Oluremi (2015) indicated that receiving teachers who had undergone training on teaching students with special needs were inadequate in number. Study of Buenaventura (2009) found out that teachers who are working with students with disabilities need further training and acquisition of tools for teaching. In contrast, the study of Gorman and Drudy (2011) found that only 37\% of the receiving did not have any in-service training in special education.

Table 1.4 shows that 18 or $48.7 \%$ of the receiving teachers have zero (0) course taken in college related to educating children with special needs, 3 or $8.1 \%$ of the receiving teachers have one (1) course taken in college related to educating children with special needs, 4 or $10.8 \%$ of the receiving teachers have two (2) courses taken in college related to educating children with special needs, 10 or $27.0 \%$ of the receiving teachers have three (3) courses taken in college related to educating children with special needs and 2 or $5.4 \%$ of the receiving teachers have four (4) courses taken in college related to educating children with special needs. It also shows that the majority of the receiving teachers do not have a course in college related to educating children with special needs. Some of the receiving teachers have taken courses in college related to educating children with special needs 
because these were included in their elective courses. The researcher found out that those respondents who have a lot of courses taken in college related to educating children with special needs are Early Childhood Education majors. In spite of having some courses regarding children with special needs, receiving teachers confessed that they needed a lot of training and workshops.

\section{Table 1.4}

Course taken in college related to educating children with special needs

\begin{tabular}{cccc}
\hline Course Taken related to Special Education & Frequency & Percent $(\%)$ \\
\hline 0 & 18 & 48.7 \\
1 & 3 & 8.1 \\
2 & 4 & 10.8 \\
3 & 10 & 27.0 \\
4 & 2 & 5.4 \\
\hline
\end{tabular}

These findings were consistent with what has been reported by Cagney (2009) which found that thirty-one (49.2\%) had taken a course in college related to special education, and thirty-two $(50.8 \%)$ had not taken such a course, and one of the respondents did not indicate whether or not he/she had taken such a course.

Table 2.1

Receiving teachers' competencies and characteristics of learners as perceived by the teachers and experts

\begin{tabular}{|c|c|c|c|c|}
\hline \multirow[b]{2}{*}{ Development and characteristics of learners } & \multicolumn{2}{|c|}{ Teachers } & \multicolumn{2}{|r|}{ Experts } \\
\hline & Mean & $\begin{array}{c}\text { Verbal } \\
\text { Interpretation }\end{array}$ & Mean & $\begin{array}{c}\text { Verbal } \\
\text { Interpretation }\end{array}$ \\
\hline A. Demonstrates respect for students first as unique human beings. & 4.46 & Proficient & 3.95 & Proficient \\
\hline $\begin{array}{l}\text { B. Demonstrates understanding in the similarities and differences } \\
\text { in human development and the characteristics between and among } \\
\text { individuals with exceptional learning needs. }\end{array}$ & 4.32 & Proficient & 3.19 & Competent \\
\hline $\begin{array}{l}\text { C. Promotes cultural sensitivity and respects students' diversity } \\
\text { including language, culture, race, gender, and special needs and } \\
\text { actively listens and pays attention to students' needs and } \\
\text { responses. }\end{array}$ & 4.32 & Proficient & 3.30 & Competent \\
\hline $\begin{array}{l}\text { D. Uses a variety of effective individualized instructional } \\
\text { strategies and resources for students with exceptional learning } \\
\text { needs }\end{array}$ & 4.24 & Proficient & 3.35 & Competent \\
\hline $\begin{array}{l}\text { E. Creates learning environments for individuals with exceptional } \\
\text { learning needs (ELN) that foster cultural understanding, safety and } \\
\text { emotional well-being, positive social interactions and active } \\
\text { engagement of individuals with exceptional learning needs }\end{array}$ & 4.46 & Proficient & 3.57 & Proficient \\
\hline $\begin{array}{l}\text { F. Increases participation of students with special needs in general } \\
\text { education settings or community settings. }\end{array}$ & 4.59 & Proficient & 3.62 & Proficient \\
\hline $\begin{array}{l}\text { G. Knowledge of instructional adaptations including alternative } \\
\text { assignments, supplemental instruction, differential standards, and } \\
\text { shortened assignments. }\end{array}$ & 4.05 & Proficient & 3.19 & Competent \\
\hline $\begin{array}{l}\text { H. Documents ongoing student progress and maintain accurate } \\
\text { records }\end{array}$ & 4.46 & Proficient & 3.92 & Proficient \\
\hline $\begin{array}{l}\text { I. Displays a sense of social responsibility and the belief that all } \\
\text { students can learn. }\end{array}$ & 4.49 & Proficient & 4.05 & Proficient \\
\hline $\begin{array}{l}\text { J. Exhibits knowledge of common characteristics of different } \\
\text { disabilities and the effect on children's education, development } \\
\text { and quality of life. (e.g., cognition, communication, motor, } \\
\text { behavior) }\end{array}$ & 3.92 & Proficient & 3.08 & Competent \\
\hline $\begin{array}{l}\text { K. Demonstrates an understanding of relevant special education } \\
\text { laws and policies }\end{array}$ & 4.22 & Proficient & 3.08 & Competent \\
\hline Mean & 4.32 & Proficient & 3.48 & Competent \\
\hline
\end{tabular}

Table 2.1 shows that the means of the responses of the receiving teachers as perceived by them range from 3.92 to 4.59. Receiving teachers perceived that they were proficient with regards to respecting students, understanding human development, promoting cultural sensitivity and respecting diversity, using a variety of 
effective individualized instructional strategies, creating positive learning environment, increasing students' participation, instructional adaptations, maintaining accurate records, believing that all students can learn, knowledge of common characteristics of different disabilities, and special education laws and policies, which are revealed by obtained means of 4.46, 4.32, 4.32, 4.24, 4.46, 4.59, 4.05, 4.46, 4.49, 3.92, and 4.22 in the data and with a verbal interpretation of proficient. An over-all mean of 4.32 suggests that receiving teachers as perceived by them are proficient.

Receiving teachers perceived that they are proficient in all items because their jobs as regular teachers are almost identical with the job description of the receiving teachers. They do not have a deep understanding with reference to every item, so they are thinking that their competence is on the level of proficient.

On the other hand, experts perceived that the receiving teachers are proficient in items regarding the respecting for students, creating learning environments, increasing students' participation, maintaining accurate records and believing that all students can learn as revealed by an obtained means of 3.95, 3.57, 3.62, 3.92, and 4.05. In items about understanding human development, promoting cultural sensitivity and respecting diversity, using variety of individualized instructional strategies, instructional adaptations, characteristics of different disabilities and special education laws, receiving teachers yielded means of 3.19, 3.30, 3.35, 3.19, 3.08, and 3.08 with verbal interpretation of competent.

Experts perceived that receiving teachers were proficient in the items that only require the love and understanding for children with special needs and documentation of students' progress. However, for those items that require individualized accommodations and modifications for children with special needs, they got a lower means. These findings are consistent with what has been reported by Nwazuoke and Mittler (2000), they observed that many receiving teachers who were in mainstream schools appeared to know little or nothing about children with special needs.

\section{Table 2.2}

Receiving teachers' competencies on assessment and curriculum as perceived by the teachers and experts

\begin{tabular}{|c|c|c|c|c|}
\hline \multirow[b]{2}{*}{ Assessment and curriculum } & \multicolumn{2}{|c|}{ Teachers } & \multicolumn{2}{|c|}{ Experts } \\
\hline & Mean & $\begin{array}{c}\text { Verbal } \\
\text { Interpretation }\end{array}$ & Mean & $\begin{array}{c}\text { Verbal } \\
\text { Interpretation }\end{array}$ \\
\hline $\begin{array}{l}\text { A. Uses pre-assessment data to develop expectations for students, } \\
\text { to differentiate instruction, and to document learning. }\end{array}$ & 4.35 & Proficient & 3.32 & Competent \\
\hline $\begin{array}{l}\text { B. Uses assessment information to identify supports and } \\
\text { adaptations required for individuals with exceptional learning } \\
\text { needs }\end{array}$ & 4.49 & Proficient & 3.46 & Competent \\
\hline $\begin{array}{l}\text { C. Sets acceptable, measurable and appropriate achievement goals } \\
\text { for student academic progress based on data available. }\end{array}$ & 3.89 & Proficient & 3.43 & Competent \\
\hline $\begin{array}{l}\text { D. Uses a variety of assessment strategies and instruments that are } \\
\text { valid and appropriate for the content and for the student } \\
\text { population. }\end{array}$ & 4.22 & Proficient & 3.41 & Competent \\
\hline $\begin{array}{l}\text { E. Identifies and uses alternative grading procedures (e.g., oral } \\
\text { presentations, projects, portfolios). }\end{array}$ & 4.32 & Proficient & 3.43 & Competent \\
\hline $\begin{array}{l}\text { F. Conducts formal and informal assessments of behavior, } \\
\text { learning, achievement, and environments to design learning } \\
\text { experiences that support the growth and development of } \\
\text { individuals with exceptional learning needs. }\end{array}$ & 4.22 & Proficient & 3.35 & Competent \\
\hline $\begin{array}{l}\text { G. Understands formal and informal assessment procedures and } \\
\text { knows how to evaluate student competencies to make instructional } \\
\text { decisions. }\end{array}$ & 4.14 & Proficient & 3.35 & Competent \\
\hline $\begin{array}{l}\text { H. Gives constructive and frequent feedback to students on their } \\
\text { learning. }\end{array}$ & 3.92 & Proficient & 3.41 & Competent \\
\hline $\begin{array}{l}\text { I. Modifies the general education curriculum for students with } \\
\text { disabilities based upon a variety of instructional techniques. }\end{array}$ & 4.14 & Proficient & 3.27 & Competent \\
\hline
\end{tabular}


Professional characteristics and level of competence of receiving teachers on mainstreaming

Table 2.2 ...continued

\begin{tabular}{|c|c|c|c|c|}
\hline \multirow[b]{2}{*}{ Assessment and curriculum } & \multicolumn{2}{|c|}{ Teachers } & \multicolumn{2}{|c|}{ Experts } \\
\hline & Mean & $\begin{array}{c}\text { Verbal } \\
\text { Interpretation }\end{array}$ & Mean & $\begin{array}{c}\text { Verbal } \\
\text { Interpretation }\end{array}$ \\
\hline $\begin{array}{l}\text { J. Develops lesson plans anchored in both general and special } \\
\text { curricula }\end{array}$ & 3.92 & Proficient & 3.27 & Competent \\
\hline $\begin{array}{l}\text { K. Uses Individual Educational Plan (IEP) objectives to plan } \\
\text { educational setting and instruction. }\end{array}$ & 3.46 & Competent & 1.62 & $\begin{array}{l}\text { Advanced } \\
\text { Beginner }\end{array}$ \\
\hline $\begin{array}{l}\text { L. Uses effective teaching procedures to include social skills } \\
\text { instruction in curriculum activities }\end{array}$ & 3.89 & Proficient & 3.32 & Competent \\
\hline M. Participates in curriculum development meetings & 4.03 & Proficient & 3.27 & Competent \\
\hline Mean & 4.08 & Proficient & 3.23 & Competent \\
\hline
\end{tabular}

Table 2.2 shows that the means of the responses of the receiving teachers as perceived by them range from 3.46 to 4.35 . Receiving teachers perceived that they can do the following: use pre-assessment data, use assessment information, set achievement goals, use variety of assessment strategies and instruments, use alternative grading procedures, conduct formal and informal assessments, evaluate students' competencies, give feedback, modify curriculum, develop lesson plans anchored on general and special curricula, use effective teaching procedures, and participate in curriculum development meeting, which are revealed by obtained means of 4.35, 4.49, 3.89, 4.22, $4.32,4.22,4.14,3.92,4.14,3.92,3.46$, and 4.03 with verbal interpretation of proficient. All items are perceived as proficient, except for the item about Individual Educational Plan, that the obtained mean is 3.46 with a verbal interpretation of competent. Similar findings were reported by Buenaventura (2009) through face-to-face in-depth interviews with receiving teachers, the researcher found out those receiving teachers could not develop individual educational plans without proper developmental assessment, the researcher concluded that this shows service gap. These findings were consistent with what has been reported by Koe Dang (2011) wherein the researcher mentioned that "efforts from teachers could possibly be wasted because an IEP might not fit the child's developmental needs." This is what the experts observed; receiving teachers' efforts were wasted due to unsuited and misused of the individual educational plan.

Receiving teachers perceived that they are proficient with almost all of the items regarding assessment and curriculum because the items are also applicable in regular students. With or without children with special needs in their class they need to do an assessment, set goals, and give feedback. They are already used to it, that is why they perceive that they are proficient. The lowest mean that they have is in the item for Individual Educational Plan, majority of the receiving teachers do not have experience in teaching with special needs, their specialization is not aligned with special education, and do not have adequate training/ workshops. That is the rationale behind being unaware of Individual Educational Plan.

In contrast with the perceived means of the receiving teachers, experts perceived that receiving teachers were just competent, not proficient in the area of assessment and curriculum. The means of the responses of the experts range from 1.62 to 3.46, wherein almost all items perceived with a verbal interpretation of competent. The means of the receiving teachers were all higher than the means obtained by the experts. Another thing that is noteworthy is the item regarding the usage of Individual Educational Plan (IEP) objectives to plan educational setting and instruction, wherein the means obtained is 1.62 with a verbal interpretation of advanced beginner. This item got the lowest means as perceived by teachers and experts under the assessment and curriculum.

It can be inferred that the receiving teachers' practices were demonstrated at an acceptable level of performance as perceived by the experts. Teachers perceive that they are doing a great job in the area of assessment, because they are always getting the general mastery of the whole class. Additionally, receiving teachers expect that the pupils who are mainstreamed into their classes could be able to perform at the same level with their regular peers. On the other hand, experts are expecting that receiving teachers could be able to cater the special needs of every student. In the area of curriculum, receiving teachers perceived that they are proficient, because modifying curriculum, developing lesson plans, teaching procedures, and participating in curriculum development meetings 
are jobs that they are familiar with. However, in the experts' perceptions, it should be done in a way where children with special needs would achieve their full potential. Teachers do not have a deep understanding about disabilities; therefore, interpreting the appropriate accommodations and modifications to children with special needs is a huge challenge to them. The worst scenario is modifying a curriculum that is not proper for the child's abilities.

Similarly, Gorman and Drudy (2011) found that receiving teachers had requested similar professional development focused mainly on the individual educational plan process, knowledge of specific disabilities, testing diagnosis and assessment, teaching methodologies (including team-teaching) relevant to children with special needs and contact with experienced teachers. These items also got lower means as perceived by the experts.

Table 2.3

Receiving teachers' competencies on collaboration as perceived by the teachers and experts

\begin{tabular}{|c|c|c|c|c|}
\hline \multirow[b]{2}{*}{ Collaboration with parents and other professionals } & \multicolumn{2}{|c|}{ Teachers } & \multicolumn{2}{|c|}{ Experts } \\
\hline & Mean & $\begin{array}{c}\text { Verbal } \\
\text { Interpretation }\end{array}$ & Mean & $\begin{array}{c}\text { Verbal } \\
\text { Interpretation }\end{array}$ \\
\hline $\begin{array}{l}\text { A. Supports general education colleagues with integrating } \\
\text { individuals with exceptional learning needs (ELN) in regular } \\
\text { environments to engage them in meaningful learning activities and } \\
\text { interactions. }\end{array}$ & 4.46 & Proficient & 4.22 & Proficient \\
\hline $\begin{array}{l}\text { B. Engages in professional activities and participate in learning } \\
\text { communities that benefit individuals with exceptional learning } \\
\text { needs. }\end{array}$ & 4.70 & Expert & 3.46 & Competent \\
\hline $\begin{array}{l}\text { C. Uses collaboration to facilitate the successful transitions of } \\
\text { individuals with exceptional learning needs (ELN) across settings. }\end{array}$ & 4.38 & Proficient & 3.49 & Competent \\
\hline $\begin{array}{l}\text { D. Collaborates with teachers and other school personnel to assure } \\
\text { non-biased, meaningful assessments and decision making. }\end{array}$ & 4.73 & Expert & 3.43 & Competent \\
\hline $\begin{array}{l}\text { E. Communicates with colleagues, follow instructions, and use } \\
\text { problem solving and other skills that will enable to work as an } \\
\text { effective member of the instructional team }\end{array}$ & 3.86 & Proficient & 3.43 & Competent \\
\hline $\begin{array}{l}\text { F. Encourages and assists families to become active participants in } \\
\text { the educational team. }\end{array}$ & 3.89 & Proficient & 3.49 & Competent \\
\hline $\begin{array}{l}\text { G. Implements collaborative and consultative relationships by } \\
\text { co-planning and co-teaching, establishing and adhering to } \\
\text { meetings, developing IEPs, and sharing expertise. }\end{array}$ & 4.38 & Proficient & 4.19 & Proficient \\
\hline $\begin{array}{l}\text { H. Participates effectively in the identification, diagnosis, } \\
\text { placement, and ongoing service of students with disabilities. }\end{array}$ & 4.00 & Proficient & 3.38 & Competent \\
\hline I. Serves as a collaborative resource person for parents/guardians, & 4.70 & Proficient & 3.97 & Proficient \\
\hline Mean & 4.34 & Proficient & 3.67 & Proficient \\
\hline
\end{tabular}

Table 2.3 shows that the means of the responses of the receiving teachers range from 3.86 to 4.73 . It will be noted that the means of the responses of the receiving teachers in the two (2) items regarding engagement in professional activities and collaboration with school personnel for non-biased, meaningful assessment and decision making, which are revealed by obtained means of 4.70 and 4.73 with verbal interpretations of excellent. The remaining six (6) items such as: supports to colleagues, transitions across settings, works as an effective member of instructional team, encourages families to become active, collaborative and consultative relationships with other professionals, participates in identification, diagnosis, placement and services, and serves as resource person, obtained a means of 4.46, 4.38, 3.86, 3.89, 4.38, 4.00, and 4.70 with verbal interpretation of proficient. An over-all mean of 4.34 suggests that receiving teachers as perceived by them are proficient.

The teaching profession always goes together with collaboration. Receiving teachers have already mastered the art of collaborating with parents and other professionals that plays a vital role in the students' education. It is a typical situation when receiving teachers communicate with parents, teachers, other family members, or anyone who can contribute for the students' progress. So, receiving teachers perceived that their collaboration skill is 
Professional characteristics and level of competence of receiving teachers on mainstreaming

exceptional. Similarly, the study of Bruster (2014) highlighted the pivotal role of receiving teachers as communicators and collaborators with other professions who were involved in educating students with special needs.

The experts perceived that receiving teachers were proficient in three (3) items including: supports to colleagues, collaborative and consultative relationships with other professionals, and served as resource person, which rendered means of 4.22, 4.19, and 3.97. While the remaining six (6) items regarding engagement in professional activities and collaboration with school personnel for non-biased, meaningful assessment and decision making, transitions across settings, works as an effective member of instructional team, encourages families to become active, and participates in identification, diagnosis, placement and services, which yielded means of 3.46, 3.49, 3.43, 3.43, 3.49, and 3.38, with verbal interpretation of competent. An over-all mean of 3.67 suggests that receiving teachers as perceived by the experts are proficient.

Experts and receiving teachers' over-all means were both proficient. Yet, it is still vivid that experts' assessment of the receiving teachers' performance is lower, compared to the result of the receiving teachers' self-assessment. The underlying rationale is the experts' point of view; the experts are special education teachers by profession. In the context of special education, collaboration with parents means teaching the parents on how to deal with their child's behavior at home or in other settings like church, cinema, mall, etc. Collaboration does not stop with communication, but also ensuring that there is a consistency in the child's performance and behavior across different settings.

Bruster (2014) mentioned that special education teachers and receiving teachers should have the opportunity to do co-teaching or team teaching to model their strategies with one another. Meanwhile, the study of Manansala (2008) revealed that receiving teachers were also necessitate to communicate and collaborate with the shadow teachers in terms of curriculum planning, instruction, behavior management, and team working.

Table 3.1

Relationship between the educational attainment of receiving teachers and their competence

\begin{tabular}{cccc}
\hline Variables & Computed Value & Critical Value & Verbal Interpretation \\
\hline $\begin{array}{c}\text { Educational Attainment and } \\
\text { Competence }\end{array}$ & $x^{2}=6.977$ & $x^{2}(2,0.05)=5.991$ & $\begin{array}{c}\text { Significant } \\
\text { Relationship }\end{array}$ \\
\hline
\end{tabular}

Since the computed value in Table 3.1 is much higher than the critical value, the null hypothesis was rejected. Thus, there is significant relationship exists between the educational attainments of the receiving teachers and their level of competence. This means that educational attainment may affect the level of competence of receiving teachers. The receiving teachers who have baccalaureate's degree tend to have a lower level of competence, because a lot of them are not into continuous education. It signifies that they are not updated with the current issues and trends concerning education. Receiving teachers, who have master's degree, tend to have a higher level of competence, because they have contemporary views in the teaching-learning processes. They are exposed with trainings/ workshops and they are observing and evaluating the other teachers' performance. Oluremi (2015) supported the findings by emphasizing the notion that teachers and other personnel who are working with students with special needs must have a minimum requirement in their educational background, because their educational background can predict their performance.

\section{Table 3.2}

Relationship between years in teaching of the receiving teachers and their competence

\begin{tabular}{cccc}
\hline Variables & Computed Value & Critical Value & Verbal Interpretation \\
\hline $\begin{array}{c}\text { Years in Teaching Children } \\
\text { with Special Needs and } \\
\text { Competence }\end{array}$ & $x^{2}=17.625$ & $x^{2}(2,0.05)=5.991$ & $\begin{array}{c}\text { Significant } \\
\text { Relationship }\end{array}$ \\
\hline
\end{tabular}


Meanwhile the computed value in Table 3.2 is much higher than the critical value, the null hypothesis was rejected. Therefore, there is significant relationship exists between the number of years in teaching children with special needs of the receiving teachers and their level of competence. Receiving teachers who have 0-2 years teaching experience in teaching children with special needs be likely to have a lower level of competence. Receiving teachers who have lower than two years of experience to be likely unequipped in teaching children with special needs, working with special education teachers, and communicating with the parents. Those above-mentioned skills take time to be mastered.

Receiving teachers who have 3-4 years of teaching experience tend to have a higher level of competence. In any kind of profession, experience is an edge. Experience helped them to be more skilled receiving teachers. Since they are the seniors, they also had the opportunities to attend trainings/ workshops, which helped them to be effective receiving teachers. Majority of the students under mainstreaming program are children with deafness or hard of hearing. Certainly, senior receiving teachers had already received a lot of trainings in sign language because the Special Education Program Department in the locale of the study launched a project on the subject of different levels of sign language.

Similarly, a Bonferroni ANOVA test comparing the mean scores of receiving teachers' attitudes revealed that, receiving teachers with more years of teaching experience would have more positive attitudes towards working with students with special needs (Cagney, 2009). Additionally, Unianu (2011) found that receiving teachers who have had more experience appear to have more self-confidence in teaching students with disabilities.

\section{Table 3.3}

Relationship between trainings/workshops attended by the receiving teachers and their competence

\begin{tabular}{cccc}
\hline Variables & Computed Value & Critical Value & Verbal Interpretation \\
\hline $\begin{array}{c}\text { Special Education Trainings/ } \\
\text { Workshops Attended and } \\
\text { Competence }\end{array}$ & $x^{2}=13.585$ & $x^{2}(2,0.05)=5.991$ & $\begin{array}{c}\text { Significant } \\
\text { Relationship }\end{array}$ \\
\hline
\end{tabular}

Subsequently the computed value in Table 3.3 is much higher than the critical value, the null hypothesis was rejected. Therefore, there is significant relationship exists between the numbers of special education trainings/ workshops attended of the receiving teachers and their level of competence. This means that trainings/ workshops may affect the level of competence of the receiving teachers. Precisely, those receiving teachers who have 0-2 trainings/workshops attended got a lower level of competence, while those who 3-4 trainings / workshops attended have got a higher level of competence. One pitfall of education graduates is how soon teachers forget things, about the teaching strategies and methodologies. Receiving teachers are going to forget what they studied, so trainings/ workshops is a must. We never stop learning, and receiving teachers should reflect that. It should be a mantra of every receiving teacher that trainings/workshops are part of the learning life cycle. It is a continuous journey of readiness and discovery. So, Department of Education owe it to the receiving teachers, the department must provide trainings.

Similar findings were reported by Oluremi (2015), results showed that teachers' attitude to students with special needs had greatly improved through workshops, seminars, and conferences attended by the receiving teachers which had developed their positive attitude to students with special needs.

Table 3.4

Relationship between the course taken in special needs of the receiving teachers and their competence

\begin{tabular}{|c|c|c|c|}
\hline Variables & Computed Value & Critical Value & Verbal Interpretation \\
\hline $\begin{array}{l}\text { Course Taken in College } \\
\text { related to Educating Children } \\
\text { with Special Needs and } \\
\text { Competence }\end{array}$ & $x^{2}=2.625$ & $x^{2}(2,0.05)=5.991$ & $\begin{array}{l}\text { No Significant } \\
\text { Relationship }\end{array}$ \\
\hline
\end{tabular}


Since the computed value in Table 3.4 is much less than the critical value, the null hypothesis was accepted. Hence, no significant relationship exists between the number of course taken in college related to educating children with special needs of the receiving teachers and their level of competence. This means that with or without course taken related to special education receiving teachers may have high or low level of competence. Receiving teachers who do not have taken a course related to special education probably can get a high level of competence because some of them had taught in schools that offer inclusion program, some of their courses in college are closely related to special education and behavioral psychology, and some are interested to teach children with special needs. On the other hand, receiving teachers who have course/s taken in college related to educating children with special needs may still get low level of competence because some of them do not immediately apply the things they learned in the course/s, and some are mismatched with the students' disability to the course taken. For example, their course is about children with autism spectrum disorder, but they are teaching children with deafness or hard of hearing.

These findings were supported by the study of Cagney (2009) were there is no statistically difference between course taken in college related to working with students with special needs and a positive overall attitude towards working with these students. Nevertheless, this issue requires further investigations.

\section{Table 4.1}

Difference between teachers' and experts' assessment on competence in development and characteristics

\begin{tabular}{cccc}
\hline Variables & Computed Value & Critical Value & Verbal Interpretation \\
\hline Receiving Teachers' & & & \\
Self-assessment and Experts & & $t(20,0.05)=2.086$ & $\begin{array}{c}\text { Significant } \\
\text { Assessment on Receiving }\end{array}$ \\
$\begin{array}{c}\text { Teachers' Competence } \\
\text { (Development and }\end{array}$ & $t=2.105$ & & \\
Characteristics of Learners) & & & \\
\hline
\end{tabular}

Since the computed value of $t=2.105$ in the Table 4.1 is much higher than the critical value $t(20,0.05)=2.086$ at $5 \%$ level of significance, the null hypothesis was rejected. Therefore, there is significant difference in the receiving teachers' competence in the area of development and characteristics of learners as perceived by the teachers and experts. It implies that receiving teachers perceived that they are proficient in this area, while experts perceived that receiving teachers are just competent. This wide difference between experts' assessment and receiving teachers' self-assessment might be explained by the tendency of the receiving teachers to overestimates their abilities and competency. It also reflected that experts are special education teachers by profession, who were in a point of direct contact with the students with special needs, and they are more sensitive to the needs of the students in the area of development and characteristics. Apparently, receiving teachers' focus is the whole class, and they are not too particular of their responsibilities about doing considerations to children with special needs. It can be inferred that receiving teachers and special education teachers must communicate to have identical goals.

The findings are concurring to the literature of Adams (2015) since mainstreaming is new to regular classes, teachers inclined to miscalculate their competence in the characteristics of learners because they are neophyte in the situation. Adams (2015) also emphasized that co-teaching with special education teacher is also a great challenge for neophyte receiving teachers.

\section{Table 4.2}

Difference between teachers' and experts' assessment on competence in assessment and curriculum

\begin{tabular}{cccc}
\hline Variables & Computed Value & Critical Value & Verbal Interpretation \\
\hline Receiving Teachers' & & & \\
Self-assessment and Experts & $t=5.654$ & $t(24,0.05)=2.064$ & Significant \\
Assessment on Receiving & & & Difference \\
Teachers' Competence & & \\
(Assessment and Curriculum) & & & \\
\hline
\end{tabular}


Since the computed value of $t=5.654$ in Table 4.2 is higher than the critical value $t(24,0.05)=2.064$ at $5 \%$ level of significance, the null hypothesis was rejected. Therefore, there is significant difference in the receiving teachers' competence in the area of assessment and curriculum as perceived by the teachers and experts. The table further indicates the huge difference is noticeable in the competence which is about the uses of Individual Educational Plan objectives to plan educational setting and instruction. Receiving teachers admitted that they are not particular for the child's Individual Educational Plan, and that's a wrong practice. Individual Educational Plan contains almost all the background and domains of development of the students, including: family background, cognitive skills, social skills, behavioral patterns, physical capabilities, etc. Individual Educational Plan is a big help for them if they will utilize it properly.

Since receiving teachers are content specialists, they tend to make and deliver the lessons in a general approach and might forgetting the considerations for children with special needs. Otherwise, they made considerations, however it is not enough in the observation of the experts. Experts are expecting them to provide accommodations and modifications in the assessment and curriculum. In order for them to match the expectations, experts as special education teachers must provide suggestions in modifications of the tests, grading scale, and assignments for children with special needs. Receiving teachers would have a variety of options to choose from and they will have an idea and confidence to create on their own.

In the study of Power (2010) he discussed the possible rationale behind the teachers' adversity in assessing students with disabilities. Power (2010) concluded that teachers had not received any training or qualification in the area of adapted assessment when they were pursuing their education degree. The lack of initial teacher training is the main cause of this predicament; this problem can be solved through development of modules specifically for adapted assessment for students with disabilities.

Table 4.3

Difference between teachers and experts' assessment on competence in collaboration

\begin{tabular}{cccc}
\hline Variables & Computed Value & Critical Value & Verbal Interpretation \\
\hline Receiving Teachers & & & \\
Self-assessment and Experts & & & \\
Assessment on Receiving & $t=3.852$ & $t(16,0.05)=2.120$ & Significant \\
Teachers' Competence & & & Difference \\
(Collaboration with Parents & & \\
and other Professionals) & & \\
\hline
\end{tabular}

Since the computed value of $t=3.852$ in Table 4.3 is much higher than the critical value $t(16,0.05)=2.120$ at $5 \%$ level of significance, the null hypothesis was rejected. Therefore, there is significant difference in the receiving teachers' competence in the area of collaboration with parents and other professionals as perceived by the teachers and experts.

Receiving teachers overestimate their competence in collaboration, maybe because there were times that they are collaborating with colleagues, parents, and other professionals but it was not observed by the experts. However, experts may ask other people with regards to how well the receiving teacher in following instructions, facilitating transition programs, developing strategies, sharing expertise, and participation in identification, diagnosis, placement, and ongoing services. Moreover, the study of Olinger (2013) revealed that receiving teachers needed to communicate and collaborate with special education teachers to set classroom expectations for students with special needs.

\section{Conclusion and recommendation}

The researcher concludes that receiving teachers generally consisted of baccalaureate and master's degree holders; it was dominated by baccalaureate's degree holders by more than three fourths. They have teaching experience to children with special needs range from 0 to 4 years; it is vivid that they do not have a long-time

60 Consortia Academia Publishing (A partner of Network of Professional Researchers and Educators) 
experience in teaching children with special needs. Predominantly, receiving teachers are lacking training/ workshops attended; almost half of them have no training/ workshops yet. Majority of the receiving teachers have no course taken in college related to special education, but those receiving teachers whose major is Early Childhood Education have course/s related to special education.

The receiving teachers as perceived by them were proficient in the three standards of development and characteristics of learners, assessment and curriculum, and collaboration with parents and other professionals. On the other hand, experts perceived receiving teachers as competent in the standard of development and characteristics of learners, and assessment and curriculum. In the standard of collaboration with parents and other professionals, experts and receiving teachers are both perceived as proficient.

There is a significant relationship between the educational attainment, number of years in teaching children with special needs, and number of special education trainings/ workshops attended by receiving teachers with the teachers' level of competence as perceived by the experts. There is no significant relationship between the courses taken in college related to educating children with special needs by receiving teachers with the teachers' level of competence as perceived by the experts.

There is a significant difference in the teachers' level of competence as perceived by the teachers and experts in the standards of development and characteristics of learners, assessment and curriculum, and collaboration with parents and other professionals. Receiving teachers overestimates their performance and they perceived it higher than the experts.

The researcher recommends that receiving teachers, special education teachers, and parents are encouraged to attend seminars or workshops intended for each of them to help them improve their respective roles. Receiving teachers handling children with deafness must have the appropriate training on Filipino sign language. The community, including the school, barangay, and nearby cooperating establishments must support programs intended for the family of these exceptional children. School Heads should give incentives to receiving teachers, like lesser loads in the office hours to enable them to practice effectively. Parents, receiving teachers, and special education teachers meeting may be arranged regularly on a monthly basis to discuss students' problems and their solutions. Similar study may be conducted in the different private and public schools providing inclusion or mainstreaming programs. Case studies are suggested to evaluate effectiveness of certain specific programs. Further and regular assessment of the level of competence of receiving teachers may be conducted.

\section{References}

Acero, V. (2008). Child and adolescent development. Rex Bookstore.

Adams, J. M. (2015). California approves tougher teacher training standards to help mainstreaming. http://edsource.org/2015/california-approves-tougher-teacher-training-standards-to-help-mainstreaming/ $\underline{91731}$

Bandura, A. (1977). Self-efficacy: Toward a unifying theory of behavioral change. Psychological Review, 84(2), 191-215. https://doi.org/10.1037/0033-295X.84.2.191

Bandura, A. (1986). Prentice-hall series in social learning theory. Social foundations of thought and action: A social cognitive theory. Prentice-Hall, Inc.

Barnes, C., Mercer, G., \& Shakespeare T. (1999). Exploring disability: A sociological introduction. Wiley.

Blanton, L., Pugach, M., \& Florian L. (2010). Preparing general education teachers to improve outcomes for students with disabilities. AACTE \& NCLD.

Boyle, C., \& Topping K. (2012). What works in inclusion? Open University Press.

Bruster, D. (2014). Comparing the perceptions of inclusion between general education and special education teachers (Unpublished dissertation thesis). Liberty University.

Buell, M., Hallam, R., Gamel-McCormick, M., \& Scheer, S. (1999). A survey of general and special education teachers' perceptions and in-service needs concerning inclusion. International Journal of Disability, 
Guzman, S. B.

46,143-152. https://doi.org/10.1080/103491299100597

Buenaventura, J. (2009). Providers' perspective in special education for children. Philippine Mental Health Association.

Cagney, T. (2009). Attitudes of general education teachers toward including students with special needs (Unpublished dissertation thesis). Iowa State University.

Dang. K. (2011). Help on the way for the IEP team. Autism Society of the Philippines.

Estrada, J. (2007). Senate Bill No. 517. Special Education Act of 2007. http: www.lawphil.net/

Gorman, E. \& Drudy, S. (2011). Professional development for teachers working in special education/inclusion in mainstream schools: The views of teachers and other stakeholders. National Council for Special Education, Special Education Research Initiative. https://doi.org/10.1111/j.1471-3802.2010.01161.x

Inciong, T. (2007). Country report: Expanding access to education and other opportunities for people with mental retardation. $18^{\text {th }}$ Asian Conference on Mental Retardation.

Manansala, M. (2008). Shadow teaching scheme for children with autism and attention deficit-hyperactivity disorder in regular schools (Unpublished dissertation thesis). University of the Philippines.

Marquardt, J. (2009). Special education: Educators' attitudes toward inclusion and its effects on collaboration (Unpublished master's thesis). University of Wisconsin-Stout.

McCray, E. D., \& McHatton, P. A. (2007). Inclinationtoward inclusion: Perceptions of elementary and secondary education teacher candidates. Action in Teacher Education. https://doi.org/10.1080/01626620.2007.10463457

Mittler, P. (2000). Working towards inclusive education. Social contexts. David Fulton Publishers.

Nwazuoke, I. A. (2000). Professional preparation of teachers of exceptional children for inclusive contexts. The Exceptional Children, 4(1\&2), 14-16.

Olinger, B. (2013). Elementary teachers' perspectives of inclusion in the regular education classroom (Unpublished dissertation thesis). East Tennessee State University.

Oluremi, F. (2015). Attitude of teachers to students with special needs in mainstreamed public secondary schools in Southwestern Nigeria: The need for a change. European Scientific Journal, 11(10). Retrieved from https://core.ac.uk/download/pdf/236407134.pdf

Picciano, A. G. (2004). Book review. Educational research primer. International Journal of Research Method in Education. Retrieved from https://eprints.soton.ac.uk/39332/

Pierce, H. (2016). Teachers criticize way district mainstreamed special education students. http://www.bakersfield.com/news/2016/02/10/teacherscriticize-way-district-mainstreamed-special-ed students.html

Power, D. (2010). The inclusion of students with disabilities in mainstream post-primary physical education from the perspective of the physical education teacher (Unpublished master's thesis). Waterford Institute of Technology.

Unianu, E. (2011). Teachers' attitudes towards inclusive education. Procedia—Social and Behavioral Sciences, 33, 900-904. https://doi.org/10.1016/j.sbspro.2012.01.252

Vazquez, M. F. (2010). Inclusionary practices: Impact of administrators' beliefs on placement decisions. (Unpublished dissertation thesis). University of Central Florida.

Vescio, V., Ross, D., \& Adams, A. (2008). A review of research on the impact of professional learning communities on teaching practice and student learning, teaching and teacher education. Teaching and Teacher Education, 24(1), 80-91. https://doi.org/10.1016/j.tate.2007.01.004

Yao, J. (2015). Inclusive and segregated special education programs: Cost analysis, student achievement and parent satisfaction (Unpublished master's thesis). University of the Philippines. 